\title{
THE CHARACTERISTIC OF BUSINESS COMPETITION SUPERVISORY COMMISSION IN INDONESIAN LEGAL SYSTEM HEADING TO SOCIETY 5.0 ERA
}

\author{
Galuh Puspaningrum \\ Doctorate Candidate at Law Faculty, \\ Jember University, \\ Jember, Indonesia \\ galuh.fh@unej.ac.id. \\ Herowati Poesoko \\ Professor of Law Facuty, \\ Jember University, \\ Research fields: Civil Procedure Law and Guarantee Law \\ L. Budi Kagramanto \\ Professor of Law Facuty, \\ Airlangga University, \\ Research fields: Competition Law \\ Dominikus Rato \\ Professor of Law Facuty, \\ Jember University, \\ Research fields: Philosophy of Law and Adat Law \\ DOI: 10.31364/SCIRJ/v8.i3.2020.P0320753 \\ http://dx.doi.org/10.31364/SCIRJ/v8.i3.2020.P0320753
}

\begin{abstract}
Society 5.0 will bring a change for Settlement Competition Law, for example an independent institutions in the field of business law creates independence in the supervision and resolution of business disputes. The Business Competition Supervisory Commission is an independent institution authorized by Law of Prohibition of Monopolistic Practices and Unfair Business Competition, to oversee the activities of business actors. According Sociological Jurisprudence, Society 5.0 affect social structure and Indonesian law enforcement.
\end{abstract}

Index Terms - Business Competition Supervisory Commission, Indonesian Legal System, Society 5.0 Era

\section{INTRODUCTION}

Indonesia is a country with a civil law system. The characteristics of the civil law system have a codified system, judges are not bound by precedents or the doctrine of stare decicis, so that the law becomes the main legal reference and the judicial system is inquisitorial. Considering that Indonesia is a state of law which prioritizes law enforcement in this case in line with the objectives of law, namely the achievement of certainty, justice, usefulness and order.
The operation of a legal system according to Kees Schuit as quoted by J.J.H. Bruggink in Arief Sidharta's book states that in the legal system consists of three elements that have a certain independence and are interrelated, namely:

a. An idiosyncratic element, formed by the system of meaning of the law consisting of rules and principles. This element, that jurors have come to terms with, is called the legal system . 
b. operational elements comprise the entire organization and institution established in a legal system.

c. and the actual element is the entire concrete conclusions and actions in relation to the system of meaning of law, both from office and from citizens within the legal system. ${ }^{1}$

Thus, the effectiveness of law enforcement depends on 3 (three) elements, namely the legal system, law enforcement agencies, and legal products. Indonesia has several dispute resolution institutions, which include; justice institutions and Alternative Dispute Resolution (ADR). The judiciary is a dispute resolution body that is constitutionally given the authority to examine and decide cases in the field of civil law, criminal law, constitutional law and business. Whereas Alternative Dispute Resolution $(\mathrm{ADR})^{2}$ emphasizes the nature of informal, voluntary, forward looking solutions, carried out in a spirit of cooperation and based on mutual interests.

History of the application of the ADR concept was a Marrekesh agreement regarding the Agreement on the Establishment of the World Trade Organization which has been ratified by the enactment of Law Number 7 of 1994, besides that Indonesia is one of the APEC Countries. By joining these two organizations, Indonesia has made a commitment in free trade. To welcome the free trade, Indonesia must prepare instruments related to their free trade. ${ }^{3}$

In its development, the dispute resolution agency has expanded, this is proven by the birth of a new concept for dispute resolution commissions or better known as non-structural independent institutions. The institution is given the authority to resolve special cases that are settled outside the judiciary and Alternative Dispute Resolution (ADR).

Free trade has an impact on business activities of business actors, namely business competition. However, it impacts on unfair and fraudulent business competition. In order to maintain harmony and balance in a trade and economy, the State forms an independent non-structural business competition supervisory institution, which is called Komisi Pengawas Persaingan Usaha (KPPU) or the Business Competition Supervisory Commission.

The KPPU concepts adopt from several countries, one of them is from European Union, the commission may commence an investigation into alleged infringements of the competition rules its own initiative or acting on a complaint. Complaints and the position of complainants are dealt with in section 13 below. In competition cases the commission has always played the parts of law-maker, policeman, investigator, prosecutor, judge, and jury, subject only to review by the court. ${ }^{4}$

The Business Competition Supervisory Commission or KPPU was formed based on Law Number 5 of 1999 concerning Prohibition of Monopolistic Practices and Unfair Business Competition, Article 1 number 18 defines that the Business Competition Supervisory Commission or KPPU is a

\footnotetext{
1 J.J.H. Bruggink translated by Arief Sidharta, Refleksi Tentang hukum, Citra Aditya Bakti, Bandung, 1999, h.140

${ }^{2}$ R.F. Saragih, Lembaga Alternatif Penyelesaian Sengketa, Jurnal Hukum dan Pembangunan, edisi Oktober-Desember, 1999, P.352

${ }^{3}$ Ibid.P.353

4 Alison Jones and Brenda Sufrin, EU Competition Law-Text, Cases and Materials, Oxford University Press, Great Britain,2011,P.1037-1038.
}

'commission formed to oversee business actors in carrying out business activities so as not to conduct monopolistic practices and or unfair business competition'. In its explanation, KPPU as an independent institution is detached of the influence of the government and other parties, which is authorized to conduct business competition supervision and impose sanctions. These sanctions are in the form of administrative actions, while criminal sanctions are the authority of the court.

Although apart from the influence of the government, KPPU has connectivity with the judiciary in terms of determining the execution of the KPPU's decision and filing an objection to the District Court. Today, the development of law is also followed by technological and industrial developments, so that law enforcement adjusts the development of technology and the era of the industrial revolution 4.0 which has been running for a long time in Indonesia, which will then be followed by a 5.0-based industry 5.0 industrial revolution. This is indicated by the application of the system of proof of business competition cases through indirect evidence, for example the case of a cartel at PT (Private Company) Yamaha Indonesia Manufacturing with PT (Private Company) Astra Honda Motor that has made an agreement in common prices for high-priced scooter matic motorcycles, where there is email evidence by President Director Yoiciro Kojima asked the marketing management group to follow the pattern of price increases as a form of commitment with Honda President Director Toshiyuka Inuma.

This paper will explore and discussing the legal standing of Business Competition Supervisory Commission in Indonesian Legal System and how to harmonize industrial era or society 5.0 to Settlement of Competition Law Dispute.

\section{RESEARCH METHODES}

The writing of this manuscript uses normative legal research that is a study conducted by studying and analyzing legal materials and legal issues related to the problem under study. Legal research is carried out to solve problems that arise, while the results to be achieved are in the form of a prescription of what should be done to resolve the issue.

The approach used in this research is the statute approach, the conceptual approach and comparative approach. The source of the primary legal material used in the writing of this manuscript is Law No.5 / 1999. Secondary legal material, covering all publications on business competition law.

\section{RESULT AND DISCUSSION}

\section{A. The Power Of Kppu and Competition Law Procedure}

The Legal standing of Business Competition Supervisory Commission (KPPU) in Indonesian law system as independent bodies who protect and supervise all businessman activity from monopoly and unfair trade competition. Meaning of KPPU as independent bodies are separate from constitutional law and state administration system bodies. They have more power such as investigate and adjudicate like justice institution or tribunal, but they can't be executor for their decision. Therefore the KPPU's position is outside the judiciary and State institutions are outside the executive function.

This is different from the business competition supervisory commission institutions in the European Union, such 
as in Germany which is famous for the Bundeskartellamt, where in Germany is very monopolized by cartel cases. The Bundeskartellamt is the most important competition authority in Germany. It is an independent higher federal authority which is assigned to the federal ministry of Economic Affairs and Energy. It is the Bundeskartellamt's responsibility to protect competition in Germany. Since 1958 the legal framework for this is the German Competition Act (Gesetz gegen Wettbewerbsbeschränkungen-GWB), which is applied and enforced by the Bundeskartellamt.

Bundeskartellamt is a multifunctional administrative institution that acts as a quasi-legislative, quasi-judicial and quasi-judicial body. Its position is under the coordination of the federal economic ministry but is independent in the examination and decision process. The head of the German Bundeskartellamt, appointed by the federal economic ministry, does not have the authority to issue decisions on business competition cases because the duties and authority of the Bundeskartellamt head are on administrative and operational matters of the institution.

Seeing the position of the Bundeskartellamt with the KPPU is very different, because the Bundeskartellamt is under the executive authority and as a quasi-judiciary, while the KPPU is neither. This is in line with the opinion of Ni'matul Huda in Lukman Hakim ${ }^{5}$, arguing that new state institutions are a form of institutional experimentation that can be in the form of councils, commissions, committees, boards, authority. These institutions, bodies or organizations were initially considered to be under executive authority, but later became independent so that they were no longer the absolute right of a chief executive to determine the appointment or dismissal of his leadership.

The legal basis for KPPU authority in examining and deciding business competition cases originating from Law Number 5 of 1999 concerning Prohibition of Monopolistic Practices and Unfair Business Competition can be referred to as the Antimonopoly Law. Where the examination of cases of business competition is an activity to maintain material law in civil law regulated in the Civil Procedure Code, even though it is not explicitly mentioned in the legislation but the characteristic of the business competition case is a civil case.

Business competition cases arise when there are reports from either business doers or consumers or both. Article 38 Paragraph (1) The Antimonopoly Law states that any person who knows that there has been a violation or suspected there has been a violation of this Law is able to report it in writing to the Commission with clear information about the violation, including the identity of the reporter.

The case inspection stage by Law No.5 / 1999 is divided into two stages, namely preliminary examination and further examination. The first procedures done by KPPU are

${ }^{5}$ Lukman Hakim, Kedudukan Hukum Komisi Negara di Indonesia (eksistensi Komisi-Komisi Negara (state auxiliary agency) sebagai Organ Negara yang Mandiri dalam Sistem Ketatanegaraan), Program Pasca Universita The legal basis for the KPPU's authority in examining and deciding business competition cases originating from Law Number 5 of 1999 concerning Prohibition of Monopolistic Practices and Unfair Business Competition can be referred to as the Antimonopoly Law. Where, the examination of cases of business competition is an activity to maintain material law in civil law regulated in the Civil Procedure Code, even though it is not explicitly mentioned in the legislation but the characteristic of the business competition case is a civil case.s Brawijaya,Malang,2010,P.139 clarification and investigation. If it is assessed that in the report and in the KPPU study there is a violation of Law No. 5/1999, a filing will be carried out including holding the title of the report. After filing, the proceeding will be continued in the commission assembly session by conducting a preliminary examination based on Article 39 Paragraph 1 of Law No.5 / 1999 stating that Based on the reports as referred to in Article 38 paragraph (1) and paragraph (2), the Commission is obliged to conduct a preliminary examination and in no later than 30 (thirty) days after receiving the report, the Commission shall determine whether or not further examination is necessary. ${ }^{6}$

In the event of a preliminary examination of the alleged violation of Law No.5/1999 is eligible to continue, the Assembly shall carry out a further examination until the Commission has passed a Decision, on the arrangements of preliminary and advanced inspections it is set out in Commission Regulation No.1 of 2010 on Matters of Procedure as stated into the flow chart of the business competition examination. ${ }^{7}$

\section{B. Law Enforcement of Business Competition Towards The Industrial Revolution 5.0 / Society 5.0.}

Technological developments in the world have brought changes to the legal system and bureaucracy, where bureaucratic mobility was initially carried out traditionally and conventionally but is now being systemized in digital information technology based on the industrial revolution 4.0, thus encouraging governments to make policies that support the 4.0 industrial revolution .

The concept of the industrial revolution 4.0 emphasizes the digitization system in the application of technology. So that in the governance and management of State institutions it is using digitization and internetization systems with the aim of achieving efficiency. Especially in law enforcement in the field of business competition involving judicial institutions that have implemented electronic courts (e-courts).

Electronic court (e-court) system is a service for Registered Users to Register Cases Online, Get Online Estimated Cost of Court Fees, Pay online, Call made by electronic channels, and Trials conducted electronically. ${ }^{8}$

1. e-Filing (Online Case Registration in Court);

2. e-Payment (Online Case Down Payment Fee);

3. e-Summons (Online Party Calling);

4. e-Litigation (online trial);

Indonesia will adopt the Society 5.0 system, this situation will also bring changes in the implementation of the legal system, because it involves artificial intelligence and technology. Through Society 5.0, artificial intelligence will transform big data in all aspects of life and Internet of Things will become a new wisdom, which will be dedicated to increase human ability to open opportunities for humanity. This transformation will help humans to live more meaningful lives. Put simply, Society 5.0 can be interpreted as a concept of a human-centered and technology-based society. The application

6 Galuh Puspaningrum,Karakteristik Hukum Acara Persaingan Usaha,Journal ADHAPER Vol.2 No.02 Juli-Desember, 2016,P.297

${ }^{7}$ Ibid. $10^{\text {th }} 2019$

${ }^{8}$ https://ecourt.mahkamahagung.go.id/diakses accessed on September 
Examples that will be applied by the Japanese government with the concept of this new civilization are as follows. ${ }^{9}$

Head of Smart Learning Center of the Republic Indonesia Teacher Association (PGRI) Richardius Eko Indrajit said there are four versions that tried to guess the picture of the 5.0 Industrial Revolution, what was it like? ${ }^{10}$

1. Cognitive system

If in the era of the Industrial Revolution 4.0, humans are still needed to repair damaged hardware, then in the Industrial Revolution 5.0 the device is automatically able to repair itself. The analogy is in 4.0 if there is a broken chair we have to come to fix it but in 5.0 The chair can fix itself, "said Prof. Indrajit on Thursday $(24 / 1)$ in Jakarta

2. Human intelligence + cognitive computing Indrajit said, experts predicted that in the 5.0 era, humans and machines would work together to solve a problem. "So it's 50-50. Doctors who operate, the robots will do things that are precise. Still the architect is human, "he explained.

3. Remote production

In the era of the Industrial Revolution 5.0, humans would be accustomed to making creations through three-dimensional printers. And not only everyday objects, but also food. "So all that's left is to press, give orders through the application, later it will be produced according to demand," Indrajit said.

4. Take over of artificial intelligence

The fourth version might sound a bit horrid, where robots can be a threat to humans. In the era of 5.0, humans will make robots equipped with artificial intelligence, with the aim of helping humans.

C. The Views Of Sociological Jurisprudence genre as a Theory In Analyzing Law Enforcement in 5.0. Era society

Sociological Jurisprudence is one form of the realization of the Legal Study Unity with its social base (including social sciences) which can then result in the law enforcement system, especially through the judicial mechanism, namely the judge's mechanism in deciding cases. The problem will arise related to the independence of judges in deciding cases. The justice system is authopoietic, but must also look at aspects of its social environment. This is where the importance of a judge is to always pay attention to the socilogic aspects and the Law Science he uses. Judges should understand the genre of Sociological Jurisprudence well so that the living law, social, political, economical and cultural aspects have a place in the judge's consideration to produce decisions that not only meet the principles of formal justice but also substantial justice even social justice in national law enforcement. ${ }^{11}$

Sociological Jurisprudence observes how law with all its characteristics is applied and used by society. When the law is implemented, there is an interaction between the law and the

9 https://karinov.co.id/revolusi-industri-5-jepang/ accessed on September $10^{\text {th }} 2019$

${ }^{10} \mathrm{http}: / / \mathrm{www}$.jurnas.com/mobile/artikel/47248/4-Prediksi-GambaranRevolusi-Industri-50/,diakses accessed on September $10^{\text {th }} 2019$

${ }^{11}$ Suteki, Desain Hukum Di Ruang Sosial,Thafa Media, Yogyakarta, behavior of the people who use it. Sociological Jurisprudence talks about the social meaning of law. The social meaning is given to the law through contacts with the social environment in which the law is applied. The Sociological Jurisprudence view stated that the rule of law cannot impose thus the contents of the rule are carried out absolutely, but in many cases subdued by the social structure in which the law is carried out. ${ }^{12}$

Research on the legal culture in Indonesia by Daniel S. Lev, as quoted by Satjipto Rahardjo, shows how the notion of law, legal procedures, in Java is defeated by harmony pattern, maintaining feelings and so on. So in this case the social structure is also a determining factor in the law and the people actually form the law by giving social meaning to it. The relationship of social structure with the law can also be observed by hindsight how the law was formed and implemented also depends on the social structure of the community. ${ }^{13}$

\section{CONCLUSION}

The 4.0 industrial revolution brought changes to law enforcement, for example in the current justice system using an electronic court system. Business Competition Supervisory Commission (KPPU) as a concept of business competition law enforcement that uses independence in the justice system. Society 5.0 systems include cognitive systems, Human intelligence plus cognitive computing, Remote production and Take over of artificial intelligence. In the view of Sociological Jurisprudence, society 5.0 is part of the social structure that brings changes to the law enforcement system in Indonesia which is carried out conventionally to the electronic system pattern.

\section{REFERENCES}

[1] Alison Jones and Brenda Sufrin, EU Competition Law-Text, Cases and Materials, Oxford University Press, Great Britain,2011.

[2]Galuh Puspaningrum,Karakteristik Hukum Acara Persaingan Usaha,Journal ADHAPER Vol.2 No.02 July-December, 2016.

[3] J.J.H. Bruggink translated by Arief Sidharta, Refleksi Tentang hukum, Citra Aditya Bakti, Bandung, 1999.

[4] Lukman Hakim, Kedudukan Hukum Komisi Negara di Indonesia (eksistensi Komisi-Komisi Negara (state auxiliary agency) sebagai Organ Negara yang Mandiri dalam Sistem Ketatanegaraan), Program Pasca Universita The legal basis for the KPPU's authority in examining and deciding business competition cases originating from Law Number 5 of 1999 concerning Prohibition of Monopolistic Practices and Unfair Business Competition can be referred to as the Antimonopoly Law. Where, the examination of cases of business competition is an activity to maintain material law in civil law regulated in the Civil Procedure Code, even though it is not explicitly mentioned in the legislation but the characteristic of the business competition case is a civil case.s Brawijaya,Malang,2010.

[5] R.F. Saragih, Lembaga Alternatif Penyelesaian Sengketa, Jurnal Hukum dan Pembangunan, edisi Oktober-Desember, 1999.

${ }^{12}$ file:///C:/Users/Galuh\%20Puspaningrum/Downloads/SEMANGAT_ PEMBAHARUAN_DAN_PENEGAKAN_HUKUM_INDONESIA.pdf, accessed on September $10^{\text {th }} 2019$

${ }^{13}$ Ibid. 
[6] Suteki, Desain Hukum Di Ruang Sosial,Thafa Media, Yogyakarta, 2013.

[7] https://ecourt.mahkamahagung.go.id/

[8] https://karinov.co.id/revolusi-industri-5-jepang/

[9] http://www.jurnas.com/mobile/artikel/47248/4-Prediksi-

Gambaran-Revolusi-Industri-5.0. 